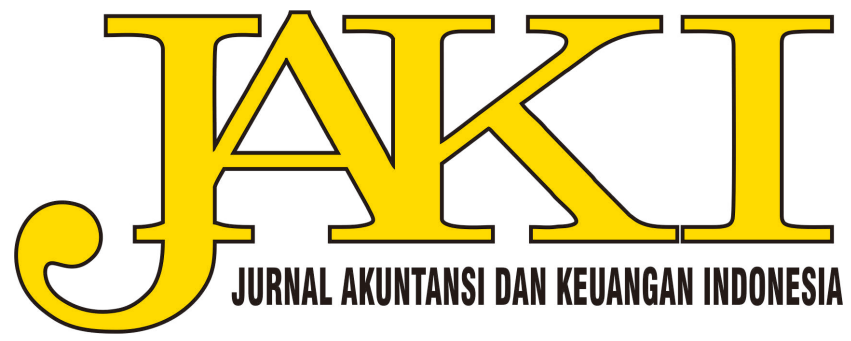

Volume 17

Issue 2 Volume 17, Issue 2, 2020

Article 2

$12-31-2020$

\title{
FOREIGN INSTITUTIONAL SHAREHOLDERS AND CORPORATE PAYOUT POLICY
}

\author{
Rahmat Setiawan \\ Airlangga University, rahmatsetiawan@feb.unair.ac.id \\ Nova Christiana \\ Airlangga University, nova.christiana-2015@feb.unair.ac.id \\ Sanju Kumar Singh \\ Airlangga University, Singhsanju44@gmail.com
}

Follow this and additional works at: https://scholarhub.ui.ac.id/jaki

Part of the Accounting Commons, Corporate Finance Commons, Finance and Financial Management Commons, and the Taxation Commons

\section{Recommended Citation}

Setiawan, Rahmat; Christiana, Nova; and Singh, Sanju Kumar (2020) "FOREIGN INSTITUTIONAL

SHAREHOLDERS AND CORPORATE PAYOUT POLICY," Jurnal Akuntansi dan Keuangan Indonesia: Vol. 17: Iss. 2, Article 2.

DOI: $10.21002 /$ jaki.2020.08

Available at: https://scholarhub.ui.ac.id/jaki/vol17/iss2/2

This Article is brought to you for free and open access by the Faculty of Economics \& Business at UI Scholars Hub. It has been accepted for inclusion in Jurnal Akuntansi dan Keuangan Indonesia by an authorized editor of UI Scholars Hub. 
Jurnal Akuntansi dan Keuangan Indonesia

Volume 17 Nomor 2, Desember 2020

\title{
FOREIGN INSTITUTIONAL SHAREHOLDERS AND CORPORATE PAYOUT POLICY
}

\author{
Rahmat Setiawan \\ Department of Management, Airlangga University \\ rahmatsetiawan@feb.unair.ac.id \\ Nova Christiana ${ }^{1}$ \\ Department of Management, Airlangga University \\ nova.christiana-2015@feb.unair.ac.id \\ Sanju K. Singh ${ }^{2}$ \\ Department of Management, Airlangga University \\ Singhsanju44@gmail.com
}

\begin{abstract}
This study examines the effect of foreign institutional shareholders (FIS) on corporate payout policy. The study employs 97 Indonesian manufacturing firms listed on the Indonesia Stock Exchange period 2011-2015. Multivariate Tobit and Logit are employed to estimate the model. The result confirms the bird in the hand theory that FISs need assurance of their investments in the emerging market. FIS has a monitoring role over the firms since they have the ability to detect the firm's quality and the agency problem within. The result confirms that the presence of the FIS in the firm has a positive and significant effect on both measures of corporate payout policy, dividend to net income and dividend to total asset. The presence of the FIS increases the propensity of the firm to pay a dividend.
\end{abstract}

Keywords: Foreign institutional shareholders, dividend payout, agency problem

\begin{abstract}
Abstrak
Penelitian ini menguji pengaruh pemegang saham institusi asing (FIS) terhadap kebijakan pembayaran perusahaan terhadap 97 perusahaan manufaktur Indonesia yang terdaftar di Bursa Efek Indonesia periode 2011-2015. Analisis multivariat menggunakan Tobit dan Logit. Hasil mengkonfirmasi bird in the hand theory bahwa FIS membutuhkan jaminan dalam berinvestasi di pasar negara berkembang. FIS memiliki kemampuan dalam mendeteksi kualitas dan masalah keagenan perusahaan sehingga secara tidak langsung FIS menjalankan fungsi monitoring. Hasil penelitian menunjukkan bahwa keberadaan FIS di perusahaan berpengaruh positif dan signifikan terhadap kebijakan dividen perusahaan. Kehadiran FIS meningkatkan kecenderungan perusahaan untuk membayar dividen.
\end{abstract}

Keywords: Pemegang saham insitusional asing, kebijakan dividen, masalah keagenan

\footnotetext{
${ }^{1}$ Student of Management Science minor in Finance, Airlangga University

${ }^{2}$ Student of Doctoral Program minor in Finance, Airlangga Univeristy
} 


\section{INTRODUCTION}

Dividend income is still an investor' objective. Firms still use a dividend to distribute surplus cash to their shareholders than share repurchase in the Indonesian market. This has been a drive on why the dividend topic is still relevant to be researched. Black (1976) argues that there are no absolute patterns in what and how firms decide their corporate payout ${ }^{3}$ policy. The difference in, such as, market, legal institutional, and ownership environment, have been reasons in how dividend policy is decided. Miller and Modigliani (1961) state that in certain circumstances in which some assumptions are applied, like no information asymmetry, no transaction cost, and no tax, the investor will be indifferent between capital gain and dividend payout.

In the perfect market of what Miller and Modigliani (1961) have mentioned, if shareholders hold good stocks, they don't have to wait for a dividend payment. The liquidity necessity is satisfied by creating a homemade dividend at a low cost and at any time. In an imperfect market like an emerging market, with high severity of agency problems, investors favor dividend payment to compensate for the uncertainty (Deshmukh 2005), and dividend can be a stable income as investors demand a return for their investments. From the governance side, dividend policy can reduce the insider's incentive to use cash flow for expropriation (Easterbrook 1984; Jensen 1986). An expropriation is an act by misusing the power owned by the insider to exploit the firm's resources for a private benefit (Faccio et al. 2001).

This study examines the impact of foreign institutional shareholders (hereafter: FIS) of the Indonesian manufacturing firms listed on the Indonesian Stock Exchange between 2011 and 2015. The FIS's impact on the corporate payout is expectedly significant in the emerging

\footnotetext{
3 The term "payout" and "dividend" refer to the firm's dividend payout policy. These terms will be used in this study interchangeably.
}

market, which suffers from uncertainty and with severe agency problems (Baba 2009). Moreover, when the ownership of a foreign institution increased, the FIS's incentive to monitor will be stronger than before (Hartzell and Starks 2003; Maug 1998).

Indonesia is one of the emerging market countries. Claessens et al. (2000) find that the firm's ownership in Indonesia is highly concentrated and about two-thirds of the firms are family firms. Highconcentrated firms always bear severe agency problems. The family, as a founder and owner, wants to keep taking control of the firm resources. Thus, the corporate decision will base on the insider's interests (Jensen and Meckling 1976). One of the corporate policies is dividend policy. The agency problem of free cash flow occurs when insiders tend to retain the earnings than to disgorge them to the shareholders (Grossman and Hart 1980; Easterbrook 1984; Jensen 1986). Rhee and Wang (2009) state that public shareholdings in Indonesia are dominated by foreign in the institutional form, such as mutual funds, pension funds, insurance funds, and brokerage. The individual shareholdings are only $5 \%$ of the total free float compared to the foreign shareholdings, which take about $70 \%$ of the free float. Thus, it is plausible that the FIS affects the corporate payout of the Indonesian firms. FIS is an institutional investor that trades in large numbers of shares and has a large stake of shareholdings with a stable portfolio (Bushee 1998). FIS is considered as sophisticated investors that can detect the firm's quality and the agency problem inside (Allen et al. 2000; Chang et al. 2015).

Dvorak (2015) adds that FIS has more trading experience and expertise than local institutional investors. However, the domestic institutional investor has more information advantages than FIS since the information will not have barriers, for example, in language and cultural distance. On the other side, any investor needs assurance of their investment in emerging countries such as Indonesia. Allen et al. (2000) and Baba (2009) state that FIS has a strong 
preference for the dividend-paying firms. Free cash flow is a source of agency problems of the firm like overspending and overinvestment by the managers, which may benefit the insiders than the shareholders, and making the dividend payment low. When FISs have increased their shareholdings, the power exerted will be bigger than before, affecting the corporate policy (Hartzell and Starks 2003). Therefore, Easterbrook (1984) and Chang et al. (2015) add that the firm will use the dividend to mitigate agency problems of the firm's financial side.

Previous studies regarding FIS have been conducted in the context of market liquidity (Maug 1998), merger and acquisition (Hartzell and Starks 2003), tax clientele investor (Allen et al. 2000), and share repurchase (Jagannathan et al. 2000). In developed countries like the U.S., Allen et al. (2000) correlate FIS with the tax bracket. Some institutional investors are not subject to tax, like mutual funds and pension funds. Then, they tend to invest and increase the stake in the dividendpaying firm (Maug 1998). This finding probably follows or does not follow the same pattern for the Indonesian market since the government applies tax to foreign investors. Wherefore the firms pay the dividend, FIS is still attracted to invest in the firm's stock. The previous studies, which have conducted in both developed and emerging markets, give mixed results. For instance, a study by Ferreira et al. (2010) does not prove that FIS impacts corporate payout policy. Then, Chiang and Lai (2015) show that FIS positively affect corporate payout policy in Taiwan. Followed the same result by Jeon et al. (2011), FIS positively affects a corporate payout in South Korea. Based on those findings, this research tries to confirm the FIS's effect on the dividend policy when conducted in an emerging market like Indonesia.

This research makes several contributions. First, contribute to the corporate finance dividend literature in the framework of agency problems and governance. Indonesia is one of the emerging countries loaded by agency problems and the low level of investor protection (Faccio et al. 2001). Some previous studies of payout policy in the Indonesian market correlate the FIS's impact on the corporate payout policy. The gap between this study and the previous is the conducted estimation approach. This study uses maximum likelihood estimations, Tobit, and Logit, which fit with the characteristics of the data observed. Using the most common approach that the previous studies employ, such as OLS, the result will likely suffer from validity issues since the dividend data are about to pay or to retain, and to be closer to zero or one.

A dividend is considered an effective means to alleviate agency problem and a result of improved corporate governance. Different from the previous studies using OLS (Chiang and Lai 2015), this study examines the impact of FIS on the corporate payout policy estimated by Tobit and Logit, which fits the data characteristics. This study shows that FIS is consistent and positively impact corporate payout, employing three measures of corporate payout such as payout ratio, dividend to total assets, and propensity to pay a dividend.

Second, this study results contribute and confirm the fact that in emerging markets the presence of FIS will encourage firms to pay dividends since the FIS can detect a firm's quality and the agency problems within. The higher the FIS stake in the firm, the better the governance and the higher the chance to gain funds for the investment projects. Then, on the investors' side, the finding is a consideration in investing in the Indonesian stock market by acknowledging the FIS effect on the dividend policy, noticing that the larger shares owned by the FIS, the better the firm governed.

Third, the result will hopefully give insight into the Indonesian authority to make a regulation that creates an appropriate business environment for FIS. In 2014, the Financial Service Authority passed a new regulation that the public shareholders (non-controlling and non-primary) are 
allowed to increase their stakes at least $7.5 \%$ of the paid capital. With this new regulation, the number of FISs may be larger than before in the Indonesian market. The findings prove that the effect of the FIS increases the rate and propensity of the dividend. Thus, the monitoring mechanism, both the firm and the market, which is done indirectly by FIS, is effective in the Indonesian market. For a reminder, this study proceeded as follows: research introduction. Section 2 explains the literature background and hypothesis building. Section 3 describes the data and methodology. Section 4 shows the results. Section 5 is the discussion, and then Section 6 is the conclusion.

\section{LITERATURE REVIEW AND HYPOTHESIS DEVELOPMENT}

\section{Corporate Governance in Indonesia, Foreign Institutional Shareholders and Payout Policy}

Indonesia, as an emerging market, is considered to have protruding agency problems and low corporate governance. Claessens et al. (2000) and Mulyani (2016) state that family firms are dominating the Indonesian capital market, making the firms become heavily concentrated and entrenched by the family members, who hold positions in the firms' board or management. The firm decision may lead to the bearing costs to their minorities. For instance, the decision for their free cash flow tends to retain than to disgorge it Easterbrook (1984). Asian Development Bank in 2000 found that the Indonesian firms have low transparency in their reporting, making the information dissemination uneven. These findings align with the truth that Indonesia is a civil law country, which La Porta et al. (2000) argue that the civil law countries have low investor protection than common law countries that pay more dividends than civil law countries.

Albeit all the findings that have stated, the FIS is not reluctant to invest in the Indonesian Market. OJK statistical data shows the uptrend of foreign ownership in the Indonesian market during the observation period 2011-2015. The big institutions, such as pension funds, insurance, or other large fiduciary institutions are dominating the large stake of foreign ownership in the Indonesian market (Rhee and Wang 2009). The behavior of these fiduciary institutions roots in the conservative act, prudential investment decisions, specifically, when they invest in the emerging market with high uncertainty (Howe 1992). The assurance for their investment will be in the first place to attain by preferably investing in firms with a low agency conflict and paying more dividends (Baba 2009; Duygun et al. 2018).

\section{Hypotheses Formulation The effect of FIS on the cash dividend propor- tion to firms 'net income}

FIS is considered as sophisticated investors who relatively have an ability to detect the firm's quality and the agency conflict within (Allen et al. 2000, Khanna and Pallepu 1999) and demand more transparency of the firms they have invested on (Duygun et al. 2018). FIS is free from the local pressures, thus make them more independent and effective at monitoring the controlling shareholders Farinha (2003) and Cao et al. (2017). However, FIS still deals with higher information asymmetry than domestic investors (Rhee and Wang 2009; Baba 2009), and the bearing risk is high in the Indonesian Market. FIS will demand a dividend payment as an assurance for their investment in the uncertainty circumstances (Baba 2009). So that, dividend-paying firms attract FIS and have considered as good governed firms Grinstein and Michaely (2005).

The proposed arguments of FIS in this study align with the agency theory framework. Since paying the dividend is preferable to FIS, it is also a means to minimize insider's incentive from misusing the firm's free cash flow (Easterbrook 1984, Jensen (1976). FIS typically hold a large stake in a firm, they can influence the firm's decision through voting rights and give an exit treatment when they are not 
satisfied (Firth 2016). FIS may increase their larger stake during their investment horizons, thus, by having a larger stake than before, FIS will increase their incentives in monitoring the firm. These arguments make the correlation of FIS to the corporate payout policy expectedly significant-positive. Some previous researches, such as Maug (1998), Hartzell and Starks (2003), Baba (2009), Jeon et al. (2011), Chiang and Lai (2015), support the positive impact of FIS on the corporate payout policy. Based on these arguments, the hypothesis is arranged as follows:

H1: FIS in Indonesia has a positive effect on the cash dividend proportion to firms' net income.

\section{The effect of FIS on the cash dividend proportion to firms' total assets}

Black (1976) states that the decision of a firm in paying the dividend is puzzled. Assuming a signaling theory is applied, firms convey their prospects to the market by paying the dividend to gain market appreciation (Bhattacharya et al. 1979). However, this view may result in some anomalies. For instance, firms may disgorge the cash to the shareholders even though they have negative earnings, or firms still pay a dividend while their investment projects are low or investing in some projects encouraged by the managers' specific interest (Howe 1992). To circumvent these issues, this study normalizes the payout ratio by scaling the annual cash dividend with the total asset, revering to the several previous studies which make using that measure, such as Li and Zhao (2008), Grinstein and Michaely (2005), Ben Nasr (2015). Based on these arguments, the hypothesis is arranged as follows:

H2: FIS in Indonesia has a positive effect on the cash dividend proportion to firms' total assets.

\section{The effect of FIS on the propensity of firms to pay dividend}

As the stated arguments of both hypotheses, we propose that the propensity to pay dividend for domestic firms in the presence of FIS is higher than firms without FIS presence. Since the FIS has the ability to detect the firms before they decide to invest, the dividend-paying firms itself already desirable for FIS (Allen and Michaely 2003). Thus, in the first place, the presence of the FIS will enhance the propensity of a firm to pay dividend. Based on the argument, the $\mathrm{H}_{3}$ is arranged as followed.

\section{H3: FIS in Indonesia has a positive effect on the propensity of firms to pay dividend.}

\section{METHOD}

\section{Research Model}

The dependent variable in this study is the dividend payout. This study employs three measures of payout policy which have been documented in several previous research. They are (1) cash dividend to net income (Payout I) (2) cash dividend to total assets (Payout II) and (3) dummy variable of propensity to pay dividend (Propensity) 1 for a dividend-paying firm and 0 otherwise. The first measure, Payout I, is the total cash dividend scaled by the total net income. This has been a common measure of corporate payout policy. The second measure of corporate payout policy is Payout II which is measured by total cash dividend scaled by total assets. Li and Zhao (2008) employ the same measure to ensure that the result will not be affected by the stock price variation in which some firms may likely to pay dividend while their earnings are negative. ${ }^{4}$

The Independent variable in this study is foreign institutional shareholders (Foreign) measured by total shares owned by FIS in the firms. The specified model controls the factors which are widely acknowledge affecting dividend policy, such as firm size, leverage, growth, and

\footnotetext{
${ }^{4}$ Following Allen and Michaely (2003), assume that the signaling theory hold, price variation may affect the result. The measure has employed by several pervious researches such as: Grinstein and Michaely (2005); Li and Zhao (2008).
} 
profitability. Fama and French (2001) suggest that big size firm and high profitability firms are firms which pay a dividend. So, firm size and profitability are controlled by Size and ROE variable. The growth factor also affects dividend policy. Based on Warrad et al. (2012) the growth factor of a firm is an expectation of future profitability through the investment opportunity. In this study, the growth factor is measured by total market value scaled by total book value of equity (Yaram 2015; Moin et al. 2019). Mancinelli and Ozkan (2006) argue that when firms bear a high debt, prevent to have cash shortfall. When firms have shortfall cash, they tend to skip dividend. Setiawan et al. (2016) suggest that most firms in Indonesia have their corporate payout is affected by the debt level. So, the leverage level is controlled by the leverage variable in the model. Time invariant and industry sectors are also controlled in the specified model. Each definition and the previous works of the variables employed are provided in table 1 below.

This study employs Tobit regression to answer $\mathrm{H}_{1}$ and $\mathrm{H}_{2}$, and logit regression to answer $\mathrm{H}_{3}$. The most common approach that often to conduct for a similar study, OLS, will make the result suffers from inconsistency and biased since the characteristic of the response variable is censored data Cameron and Triverdi (2005). Censored data in this study implies that the value of the response variable cannot be negative, but within the range 0 to 1 , and for the logit model, which is the discrete-dichotomous response, 1 or 0 . This study also develops $\mathrm{H}_{3}$ to support the study's finding, $\mathrm{H}_{1}$, and $\mathrm{H}_{2}$. The results from the estimation will be parallel supporting the findings. Below, the latent regression models are specified, respectively, for Tobit and logit:

$$
y_{t}^{*}=x_{t}^{t} \beta+\mu_{t}
$$

which $y_{t}^{\sharp}$ is a continuous response of the dividend ration, which is unobserved, within the range 0 to 1 and satisfies the observed specifications below:

$$
y_{t}=\left\{\begin{array}{c}
y_{t}^{*} \text { if } y_{t}^{*}>0 \\
\text { 0otherwise }
\end{array}\right.
$$

$x_{t}$ is the exogenous variable to the $y_{t}^{\sharp} \beta$ is the parameter and $\mu_{t}$ is the error term, which is both are estimated by maximizing the function's log-likelihood.

For logit regression,

$$
y_{t}=x_{t}^{t} \beta+\mu_{t}
$$

Which $y_{t}$ is the dichotomous response, 1 or 0 , and satisfies the specifications below:

$$
y_{t}=\left\{\begin{array}{c}
1=\text { paying dividend } \\
0=\text { not paying dividend }
\end{array}\right.
$$

$x_{t}$ is exogenous variable to the $y_{t}$, with conditional probability $\operatorname{Pr}\left(y_{t}=1 \mid x_{t}\right) \cdot \beta$ is the parameter and $\mu_{t}$ is the error term, which is both estimated by exerting logistic distribution to maximize the probability of an event, in this study is the propensity to pay a dividend to be likely happening.

Therefore, the baseline models for this

\begin{tabular}{|c|c|c|}
\hline Payout I & $=$ & $\begin{array}{l}\text { Dividend payout ratio } \mathrm{I} \text { of firm } \mathrm{i} \text { in } \\
\text { the year } \mathrm{t}\end{array}$ \\
\hline Payout II & $=$ & $\begin{array}{l}\text { Dividend payout ratio II of firm } \mathrm{i} \\
\text { in the year } \mathrm{t}\end{array}$ \\
\hline Propensity & $=$ & $\begin{array}{l}\text { Dummy variable of propensity to } \\
\text { pay dividend of firm } i \text { in the year } t \text {, } \\
1 \text { for dividend payers, } 0 \text { otherwise }\end{array}$ \\
\hline Foreign & $=$ & $\begin{array}{l}\text { Foreign institutional shareholders } \\
\text { of firm } \mathrm{i} \text { in the year } \mathrm{t}\end{array}$ \\
\hline Controls & $=$ & $\begin{array}{l}\text { Control variables of firm } i \text { in the } \\
\text { year } t\end{array}$ \\
\hline$\varepsilon$ & $=$ & Error of firm $\mathrm{i}$ in the year $\mathrm{t}$ \\
\hline$\alpha$ & $=$ & Intercept \\
\hline$\beta_{1-5}$ & $=$ & Regression coefficient \\
\hline
\end{tabular}
study are specified as follows:

$$
\begin{aligned}
& \text { Tobit(PayoutI })_{i, t}=\alpha_{i, t}+\beta_{i, t} \text { Foreign }_{i, t}+\gamma_{i, t} \text { Controls }_{i, t}+\varepsilon_{i, t} \\
& \text { Tobit(PayoutII })_{i, t}=\alpha_{i, t}+\beta_{i, t} \text { Foreign }_{i, t}+\gamma_{i, t} \text { Controls }_{i, t}+\varepsilon_{i, t} \\
& \text { Logit(Propensity })_{i, t}=\alpha_{i, t}+\beta_{i, t} \text { Foreign }_{i, t}+\gamma_{i, t} \text { Controls }_{i, t}+\varepsilon_{i, t}
\end{aligned}
$$

Where: 
Table 1

Variable Definitions

\begin{tabular}{|c|c|c|c|}
\hline No & Variables & Definitions and Measurement & Researchers \\
\hline 1 & Payout I & $\begin{array}{l}\text { Dividend payout I, measured by total cash dividend } \\
\text { scaled by net income. }\end{array}$ & $\begin{array}{l}\text { Baba (2009), Jeon et al. } \\
\text { (2009) }\end{array}$ \\
\hline 2 & Payout II & $\begin{array}{l}\text { Dividend payout II, measured by total cash dividend } \\
\text { scaled by total asset. }\end{array}$ & $\begin{array}{l}\text { Li and Zhao (2008), Jeon et } \\
\text { al. (2009). }\end{array}$ \\
\hline 3 & Propensity & $\begin{array}{l}\text { Dividend payer firms parameter, measured by a dummy } \\
\text { variable, } 1 \text { for dividend payers and } 0 \text { otherwise. }\end{array}$ & $\begin{array}{l}\text { Baba (2009), Chiang and } \\
\text { Lai (2015) }\end{array}$ \\
\hline 4 & Foreign & $\begin{array}{l}\text { Foreign institutional shareholders (FIS), measured by } \\
\text { the percentage of shares owned by foreign institutional } \\
\text { to total outstanding shares. }\end{array}$ & Chiang and Lai (2015) \\
\hline 5 & Size & Firm's size, measured by Ln of total asset. & Fama and French (2001) \\
\hline 6 & ROE & $\begin{array}{l}\text { Firm profitability, measured by net income scaled by } \\
\text { total equity. }\end{array}$ & $\begin{array}{l}\text { Francis et al. (2004); } \\
\text { Pagalung (2006) }\end{array}$ \\
\hline 7 & Growth & $\begin{array}{l}\text { Firm growth measures investment opportunity. Firm } \\
\text { growth is measured by total market value scaled by total } \\
\text { book value of equity. }\end{array}$ & $\begin{array}{l}\text { Fama and French (2001), } \\
\text { Jeon (2012), Yaram (2015), } \\
\text { Moin et al. (2019) }\end{array}$ \\
\hline 8 & Leverage & $\begin{array}{l}\text { Firm leverage level, measured by total debt scaled by } \\
\text { total asset. }\end{array}$ & $\begin{array}{l}\text { Mancinelli and Ozkan } \\
\text { (2006), Setiawan et al. } \\
\text { (2016) }\end{array}$ \\
\hline
\end{tabular}

Table 2.1

Firms Sample of Manufacturing Sector 2011-2015

\begin{tabular}{lcccc}
\hline & \multicolumn{4}{c}{ Manufacturing Industry } \\
\cline { 1 - 4 } & $\begin{array}{l}\text { Basic \& Chemicals } \\
\text { Sector }\end{array}$ & $\begin{array}{c}\text { Miscellaneous } \\
\text { Sector }\end{array}$ & $\begin{array}{c}\text { Consumer } \\
\text { Goods Sector }\end{array}$ & Total \\
\hline Firms & 41 & 21 & 35 & 97 \\
Observations & 205 & 105 & 175 & 485 \\
\hline
\end{tabular}

\section{Variables Definition Sample}

This study uses Indonesian manufacturing firms that are listed on the Indonesia Stock Exchange period 2011-2015. This study defines some considerations using the manufacturing sector in the observed period. First, the manufacturing firms' reports are fully available during 2011-2015. The completeness of the data supports this study's property, which keeps the observations in a balanced series. The period of 2011-2015 is considered a stable period in the context of macroeconomic circum- stances. So, neither lag nor crisis can condition the result of this study. Second, manufacturing firms have consisted of a larger portion of the Indonesian capital market composition than other sectors and have indirectly give a significantly big contribution to the GDP. Based on these considerations, manufacturing firms will have a bigger propensity to disgorge their cash as a dividend or to retain it. Firms with incomplete reports and negative payouts are dropped from the estimation. The sampling ends up with 97 firms or 485 observations. 
Table 2.2

The Proportion and Payout Ratio of Dividend-Paying Firms per Industry Sector 2011-2015

\begin{tabular}{lccc}
\hline & \multicolumn{3}{c}{ Manufacturing Industry } \\
\cline { 2 - 4 } & $\begin{array}{c}\text { Basic \& Chemicals } \\
\text { sector }\end{array}$ & $\begin{array}{c}\text { Miscellaneous } \\
\text { sector }\end{array}$ & $\begin{array}{c}\text { Consumer Goods } \\
\text { sector }\end{array}$ \\
\hline $\begin{array}{l}\text { Proportion of } \\
\text { dividend paying firms }\end{array}$ & 0.509 & 0.514 & 0.560 \\
\hline $\begin{array}{l}\text { Payout ratio of } \\
\text { dividend per industry } \\
\text { sector }\end{array}$ & 0.121 & 0.168 & 0.262 \\
\hline
\end{tabular}

Table 3

Payout Ratio of dividend Paying Firms with FIS and non-FIS

\begin{tabular}{|c|c|c|c|c|c|c|c|}
\hline \multirow{2}{*}{$\begin{array}{l}\text { Dividend-Paying } \\
\text { Firms }\end{array}$} & \multicolumn{3}{|c|}{ Payout I } & \multicolumn{3}{|c|}{ Payout II } & \multirow{2}{*}{$\begin{array}{c}\text { Propensity } \\
\text { N }\end{array}$} \\
\hline & Mean & Med. & $\mathbf{N}$ & Mean & Med. & $\mathbf{N}$ & \\
\hline Non-Foreign (T1) & 0.326 & 0.306 & 87 & 0.055 & 0.027 & 87 & 87 \\
\hline \multicolumn{8}{|l|}{$\begin{array}{l}\text { Foreign } \\
\text { Shareholders: }\end{array}$} \\
\hline Low (T2) & 0.300 & 0.300 & 73 & 0.090 & 0.024 & 73 & 73 \\
\hline High (T3) & 0.469 & 0.388 & 81 & 0.042 & 0.029 & 81 & 81 \\
\hline $\mathbf{N}$ & & & 241 & & & 241 & 241 \\
\hline
\end{tabular}

$\mathrm{T}(1,2,3):$ Tercile $1^{\text {st }}, 2^{\text {nd }}$, and $3^{\text {rd }}$

\section{RESULTS}

\section{Descriptive Statistics of Sample Data}

Table 2.1, the data show the manufacturing industry with its sectors in this current study. Basic \& Chemicals Industry consists of 7 sub-sectors. Miscellaneous Industry consists of 4 sub-sectors. Consumer goods consist of 5 sub-sectors. The table shows that the basic and chemical sector is a sector with the highest number of sample firms of all, which about 41 firms, followed by the consumer goods and miscellaneous sector, respectively, and 35 and 21 firms $^{5}$. The consumer goods sector

5 The complete descriptive of paying and nonpaying dividend firms are available in appendix 1. is a sector that consists of the most proportion of dividend-paying firms and the highest payout ratio of all sectors. Both are shown in table 2.2.

Table 3 presents the dividend-paying firms overview based on the presence of the FIS. There are non-FIS and FIS firms which both are dividend-paying firms. Foreign shareholders amount is dividedinto terciles which are non-FIS, low FIS, and high FIS. There are 87 of the non-FIS firms or firms with local ownership that pay about $33 \%$ of dividend payout. There are 154 firms of FIS, which consist of firms with high (81 firms) and low FIS (73 firms). Firms with higher FIS averagely pay more dividends (47\%) than firms with lower FIS (30\%). 
Table 4

Descriptive Data of Research Variables

\begin{tabular}{lrrrrrrrr}
\hline Variables & Mean & S.D. & P10 & P25 & P50 & P75 & P90 & N \\
\hline Payout I & 0.182 & 0.244 & 0 & 0 & 0 & 0.318 & 0.498 & 485 \\
Payout II & 0.298 & 0.692 & 0 & 0 & 0 & 1 & 1 & 485 \\
Propensity & 0.497 & 0.501 & 0 & 0 & 0 & 1 & 1 & 485 \\
Foreign & 0.344 & 0.341 & 0 & 0 & 0 & 1 & 1 & 485 \\
Size & 14.203 & 1.586 & 12.398 & 13.155 & 14 & 14.984 & 16.570 & 485 \\
Leverage & 0.473 & 0.232 & 0.197 & 0.292 & 0.472 & 0.620 & 0.766 & 485 \\
ROE & 0.147 & 0.641 & 0.0004 & 0.003 & 0.016 & 0.042 & 0.141 & 485 \\
Growth & 1.193 & 0.921 & 0.428 & 0.688 & 1.00 & 1.50 & 2.00 & 485 \\
\hline
\end{tabular}

Table 4 provides the descriptive data of firms' payouts, foreign shareholders and firm's characteristics of manufacturing firms period 2011-2015 with 485 total observations. Payout $\mathrm{I}$ is the ratio of cash dividend to net income indicates a low level of dividend payments of the manufacturing firms $(M=.18, M d n=0)$. The finding confirms (Faccio et al. 2001) that Indonesia has considered a country that pays a low-level dividend. The propensity to pay a dividend for the manufacturing firm is $50 \%$ of the total observations or about 241 observations. The payout level and the propensity to pay is above the median. This means the data are skewed to the left. Since the data is skewed to the left, multivariate Tobit is suggested than estimating using OLS in order to prevent biased results (Cameron and Triverdi 2009). The firm's size of the employed firm samples is relatively high and highly varied from each other $(M=14.20, S D=$ 1.59; $M d n .=14.00)$. The firms bear a moderate debt level $(M=.47 ; M d n=47)$.

Table 5 presents the correlation between each variable in this study. Payout I, II, and Propensity as expected are highly correlated, respectively, $r(485)=.97, p<$ $.01 ; r(485)=.93, p<.01 ; r(485)=.93, p<$ .01 . This finding means that each measure is similar in measuring corporate payout.
Foreign shareholder's dummy variable shows a positive correlation to each dividend payout measure indicates that firms with foreign shareholders tend to have a higher dividend rate and a higher propensity to pay a dividend. Other controls show positive and negative correlations, like Size and ROE, are showing positive correlation and Leverage is showing a negative correlation.

Table 6 shows the expected signs of the variables employed. Foreign as the main independent variable is expected to have a positive effect on the payout policy. Control variables such as Size and ROE are expected to have a positive effect on the payout policy, while Leverage and Growth are expected to have a negative effect on the payout policy. The estimation sign column shows the result of the estimated model. As expected, variable Foreign has a positive effect on the payout policy, as well as control variables such as Size and ROE

(Table 7; Payout 2). Leverage shows a negative effect on the payout policy as expected. Meanwhile, variable Growth is expected to be negative, but the result shows a positive effect of Growth on the payout policy. 
Table 5

Spearman Correlation Matrix

\begin{tabular}{|c|c|c|c|c|c|c|c|c|}
\hline & Payout I & Payout II & Propensity & Foreign & Size & Leverage & ROE & MVBV \\
\hline Payout I & 1 & & & & & & & \\
\hline \multirow[t]{2}{*}{ Payout II } & $0.968 * * *$ & 1 & & & & & & \\
\hline & $(0.00)$ & & & & & & & \\
\hline \multirow[t]{2}{*}{ Propensity } & $0.927 * * *$ & $0.927 * * *$ & 1 & & & & & \\
\hline & $(0.00)$ & $(0.00)$ & & & & & & \\
\hline \multirow[t]{2}{*}{ Foreign } & $0.115^{* *}$ & $0.112^{* *}$ & $0.059^{* *}$ & 1 & & & & \\
\hline & $(0.011)$ & (0.014) & $(0.019)$ & & & & & \\
\hline \multirow[t]{2}{*}{ Size } & $0.376^{* * *}$ & $0.368 * * *$ & $0.356 * * *$ & -0.063 & 1 & & & \\
\hline & $(0.00)$ & $(0.00)$ & $(0.00)$ & $(0.164)$ & & & & \\
\hline \multirow[t]{2}{*}{ Leverage } & $-0.296 * * *$ & $-0.346^{* * *}$ & $-0.288 * * *$ & -0.061 & $0.195 * * *$ & 1 & & \\
\hline & $(0.00)$ & $(0.00)$ & $(0.00)$ & $(0.183)$ & $(0.00)$ & & & \\
\hline \multirow[t]{2}{*}{ ROE } & $0.469 * * *$ & $0.557 * * *$ & $0.442 * * *$ & $0.207 * * *$ & $0.201 * * *$ & 0.046 & 1 & \\
\hline & $(0.00)$ & $(0.00)$ & $(0.00)$ & $(0.00)$ & $(0.00)$ & $(0.311)$ & & \\
\hline \multirow[t]{2}{*}{ Growth } & $0.315^{* * *}$ & $0.343 * * *$ & $0.279 * * *$ & $0.123 * * *$ & $0.325^{* * *}$ & -0.007 & $0.354^{* * * *}$ & 1 \\
\hline & $(0.00)$ & $(0.00)$ & $(0.00)$ & $(0.007)$ & $(0.00)$ & $(0.879)$ & (0.00) & \\
\hline
\end{tabular}

$* * * \operatorname{Sig} .1 \%$, ** Sig. 5\%, * Sig. 10\%. The number in the parentheses is the p-value

Table 6

Expected and Estimation Result Signs of Research Variables on the Payout Policy

\begin{tabular}{lcc}
\hline Variables & Expected Sign & Estimation Result Sign* \\
\hline Foreign & + & + \\
Size & + & + \\
Leverage & - & + \\
ROE & + & + \\
Growth & - & +
\end{tabular}

* Column "Estimated Sign" is based on the result of the estimation from Table 7 
Table 7

The Result of Foreign Institutional Shareholders Estimation on Corporate Payout

\begin{tabular}{|c|c|c|c|}
\hline & \multicolumn{3}{|c|}{ Corporate Payout } \\
\hline & Payout I & Payout II & Propensity \\
\hline & Tobit $(t)$ & Tobit $(t)$ & Logit $(z)$ \\
\hline \multirow[t]{2}{*}{ Foreign } & $0.122 * * *$ & $0.503 * * *$ & $0.406 *$ \\
\hline & $(2.43)$ & (3.33) & $(1.70)$ \\
\hline \multirow[t]{2}{*}{ Size } & $0.10 * * *$ & $0.189 * * *$ & $0.770 * * *$ \\
\hline & (9.49) & (5.19) & (7.76) \\
\hline \multirow[t]{2}{*}{ Leverage } & $-0.759 * * *$ & $-1.939 * * *$ & $-4.727 * * *$ \\
\hline & $(-7.38)$ & $(-6.67)$ & $(-6.48)$ \\
\hline \multirow[t]{2}{*}{ ROE } & 0.02 & $0.212 *$ & 0.013 \\
\hline & $(0.47)$ & (1.75) & $(0.07)$ \\
\hline \multirow[t]{2}{*}{ Growth } & $0.103 * * *$ & $0.248 * * *$ & $0.581 * * *$ \\
\hline & $(3.65)$ & (3.67) & $(4.06)$ \\
\hline \multirow[t]{2}{*}{ Intercept } & $-1.168 * * *$ & $-2.540 * * *$ & $-9.225 * * *$ \\
\hline & $(-8.00)$ & $(-4.97)$ & $(-7.41)$ \\
\hline Year & Yes & Yes & Yes \\
\hline Sectors & Yes & Yes & Yes \\
\hline $\begin{array}{r}\text { Pseudo- } \\
\text { R2 }\end{array}$ & 0.318 & 0.189 & 0.277 \\
\hline N obs & 485 & 485 & 485 \\
\hline
\end{tabular}

*** Sig. 1\%,** Sig. 5\%, * Sig. 10\%. The number in the parantheses is the $p$-value

Table 7 provides the estimation results of foreign shareholders on corporate payout policy. Foreign shareholders is positive and significant on the Payout I $(\beta=$ $0.122, t=2.43, p<0.01)$, Payout II $(\beta=$ $0.503, t=3.33, p<0.01)$, and Propensity $(\beta$ $=0.406, z=1.70, p<0.10)$. The results show that foreign shareholders impact the dividend payout policy of manufacturing firms in Indonesia. The presence of foreign shareholders in the firms increases the payout level and propensity to pay a dividend. These findings confirm the previous studies by Baba (2009), Chiang and Lai (2015), and Jeon et al. (2011).

Table 8 panels $\mathrm{A}$ and $\mathrm{B}$ provide the marginal effect and odd ratio of FIS on the corporate payout of manufacturing firms period 2011-2015. In panel A, the results show that the FIS gives a significant positive impact on the corporate payout, Payout I and Payout II. The increasing of FIS by $1 \%$ will increase the magnitude of Payout I by about $12.2 \%$ when all variables at their mean values. A similar result for the Payout II model, the increase of FIS by 
Table 8

The Marginal Effect and Odd Ratio of Foreign Institutional Shareholders on the Payout

A. The Marginal Effect of Foreign institutional shareholders On Corporate Payout

\begin{tabular}{lc}
\hline Payout I & $0.122 * * *$ \\
Payout II & $(2.44)$ \\
& $0.503 * * *$ \\
\hline
\end{tabular}

B. Odd Ratio of Foreign Institutional Shareholders on the Payout

$\begin{array}{ll}\text { Propensity } & 1.50 * * *\end{array}$

(1.70)

*** Sig. $1 \%$, ** Sig. 5\%, * Sig. 10\%. The number in the parentheses is the $p$-value

$1 \%$ will increase the magnitude of Payout II about $50.3 \%$ when all variables at their mean values. In table 8 Panel $\mathrm{B}$ provides the odd ratio of FIS to the firm's propensity to pay dividend. The results show that the bigger domination of FIS shares in a firm, the bigger propensity to pay dividends about 1.50 times bigger compared with the firm without FIS or fully domestic ownership.

\section{Discussion}

From the analysis, this study finds that the Indonesian capital market has been dominated by foreign investors in the form of institutions. Chemicals industries are dominant in the manufacturing sector of Indonesia which has 7 sub-sectors and about 41 firms observed in this study, followed by miscellaneous and Basic \& Chemical Industry. It implies that the chemical industries drive the Indonesian manufacturing sector. However, the proportion of firms and the highest rate of dividend payout ratios are the only brought by the consumer goods industry.

Almost $50 \%$ of the firms in the manufacturing sector have FIS in their shareholding compositions. This means that stocks of manufacturing firms are still foreign investors' preference in their invest- ment portfolios. However, the surprise from the findings shows that firms which have non-FIS are still dividend-paying firms with $33 \%$ of the firms' total income. Then, firms with a high presence of FIS pay more dividends, about $47 \%$ of the firms' total income than to the firms with low FIS which about $30 \%$ of firms' total income. This implies that the most firms in the Indonesian manufacturing sector are at the growing phase firms which need more funding to expand their business and FIS are long investment horizon investor so that the FISs will invest at the good quality firms for the sake of future return yet still pay a dividend even though those firms pay a lower rate of payout.

The FISs are considered as sophisticated investors which able to detect the firm's quality and will stick with firms that have good governance by paying the dividend. This finding supports previous studies by Khanna and Pallepu (1999), Allen et al. (2000), Baba (2009). Meanwhile, on the other side, the tax regulation imposed by the Indonesian government reminds unstable which keeps changing from time to time or from regime to regime. This will make the FIS stick with the firms which have a flexible rate in paying the surplus cash. Dividend-paying firms give FIS as 
surance of their investment in the Indonesian capital market which is considered as an uncertain market.

However, when the models ran, the findings show that the presence of FIS is statistically significant in its effect on the dividend policy. The finding is consistent and supports the hypotheses that the presence of FIS will give a positive impact on the likelihood of the firm to pay dividend and support the previous studies by Chiang and Lai (2015), Jeon et al. (2011), Baba (2009). These findings are supported by the coefficient and marginal effect of the FIS on each payout measures. However, the impact of FIS on dividend policy is slightly small for Payout I measures (12\%), but higher for Payout II $(50 \%)$, also for the likelihood of a firm to pay dividend (41\%). This is a surprise since payout I is a common payout measure throughout the majority of previous researches. Both the coefficient and the marginal value of FIS on the Payout II are higher than the Payout I and III. However, these findings are consistent with this research hypothesis that FIS gives a positive impact on Payout II. Payout II is a proportion of cash dividend to the firms' total assets. Thus, this is consistent with Fama and French (2001) that the bigger the firms, the bigger ability of firms in paying dividend. For the control variables, the most factor, which affects the manufacturing firms in the Indonesian market to pay dividend, is the leverage factor. It is believed and scientifically proven that firms will make a priority in managing their cash flow by using their cash to pay off the debt. The result also shows that the growth factor gives the opposite effect on each payout measure. This is different than what this study has predicted. It is believed that the firms with a high investment opportunity signal their future prospect through dividend payments in Indonesian manufacturing firms.

\section{CONCLUSION}

This study examines the effect of foreign institutional shareholders on corporate payout policy using manufacturing firms listed on the Indonesia Stock Exchange period 2011-2015 and generating about 97 sample firms or 485 observations. The specified model using firm size, leverage level, and profitability level by investors as controls. In order to alleviate the variation in each sector and time, the model also controls the year variant and industry sector. Dividend payout is measured by the ratio of cash dividend to net income, cash dividend to total assets, and dichotomous indicator of payer and non-payer firm.

First, the result shows the fact that FIS is impacting corporate payout policy. Several studies have conducted foreign institutions as explanatory of corporate policy and this study is one of those studies which has confirmed the fact. This study shows that the impact of FIS on the corporate payout is positive statistically and economically significant. This is confirming the bird in the hand theory that FIS wants assurance of their investment in the emerging country. This finding confirms the similar research which is conducted by (Baba 2009; Chiang and Lai 2015; Jeon et al. 2011). Firms with a presence of FIS has a high-level payout and increase the propensity to pay a dividend. In conclusion, dividend-paying firms attract FIS. This confirms the signaling theory that in order to attract sophisticated investors which able to detect the firm's quality and agency problem, firms will use dividends as a signal to the market. Improved governance is shown by the dividend payment when the FIS captures this, FIS will invest and/or raise the stakes in the firm. This way will eventually affect corporate policy. The finding also confirms that dividend payment is a means to mitigate agency problems in the firms and the presence of FIS in the firms is an effective way to maintain good governance by encouraging insiders to pay dividend.

However, the current study has several limitations that can be suggestions for further research. The limitations may come from the data and the model. First, this five-year study does not include all of the non-financial firms. Second, the research model may be arbitrary and does not em 
ploy other factors which empirically affecting the payout policy; for instance, the profitability of assets, firm liquidity, and controlling shareholder, nevertheless, the authors believe that several important factors already employed in explaining the impact of FIS on the payout policy which based on the previous studies explained earlier in the current study. Regarding these limitations, the results derived from the manufacturing sides only and do not explain the payout behavior for the whole non-financial firms in the observed market. The authors suggest utilizing most of the non-financial firms of the Indonesian market in longer series than this current study has and employ more essential factors for further research, so the impact of FIS on the Indonesian listed firms will give wider inference. Then, this study is hopefully able to give insight to the investors about the dividend of manufacturing industries in Indonesia and hopefully, the study is able to give insight in order to improve firm governance through dividend payment.

\section{REFERENCES}

Allen, F. A., E. Bernardo, and I. Welch. 2000. A theory of Dvidends Based on Tax Clienteles. The Journal of Finance, 55 (6), 2499-2536.

Allen, F., and R. Michaely. 2003. Payout Policy. Handbook of the Economics of Finance 1(A), 337-429.

Baba, N. 2009. Increased Presence of Foreign Investors and Dividend Policy of Japanese Firms. Pacific-Basin Finance Journal, 17, 163-174.

Ben-Nasr, H. 2015. Government Ownership and Dividend Policy: Evidence from Newly Privatized Firms. Journal of Business Finance \& Accounting, 42 (5-6), 665-704.

Bhattacharya, S. 1980. Nondissipative Signaling Structures and Dividend Policy. The Quarterly Journal of Economics, 95 (1), 1-24.
Black, F. 1976. The Dividend Puzzle. The Journal of Portfolio Management Winter, 2 (2), 5-8.

Bushee, B., J. 1998. The Influence of Investors on Myopic R\&D Investment Behaviour. The Accounting Review, 73 (3), 305-333.

Cao, L., Y. Du, and J. O. Hansen. 2017. Foreign Institutional Investors and Dividend Policy: Evidence from China. International Business Review, 26 (5), 816-827.

Cameron, C., and P. K. Trivedi. 2009. Tobit and Selection Models, Micronometrics Using Stata. Texas: Stata Press Publication.

Chang, K., E. Kang, and Y. Li. 2016. Effect of Institutional Ownership on Dividends: An Agency-Theory-Based Analysis. Journal of Business Research, 69 (7), 2551-2559.

Chiang, Y. C., and B. S. Lai. 2015. Dividend Payout Policy Decision: The Role of Foreign Ownership. Investment Management and Financial Innovations, 12 (2), 205-213.

Claessens, S., S. Djankov, J. P. Fan, and L. H. Lang. 2000. Expropriation of Minority Shareholders in East Asia. Journal of Financial Economics, 58, 81-112.

Deshmukh, S. 2005. The Effect of Asymmetry Information on Dividend Policy. Quarterly Journal of Business and Economics, 44 (1/2), 107-127.

Dvorak, T. 2015. Do Domestic Investors Have an Information Advantage? Evidence from Indonesia. The Journal of Finance, 60 (2), 817-839.

Duygun, M., Y. Guney, and A. Moin. 2018. Dividend Policy of Indonesian Listed Firms: The Role of Families and The State. Economic Modeling, 75, 336354. 
Easterbrook, F., H. 1984. Two AgencyCost Explanations of Dividends. The American Economic Review, 74 (4), 650-659.

Faccio, M., L. H. P. Lang, and L. Young. 2001. Dividends and Expropriation. The American Economic Review, 91 (1), 54-78.

Fama, E.F., and K. R. French. 2001. Disappearing Dividends: Changing Firm Characteristics or Lower Propensity to Pay? Journal of Financial Economics, 60 (1), 3-44.

Farinha, J. 2003. Dividend Policy, Corporate Governance and The Managerial Entrenchment Hypothesis: An Empirical Analysis. Journal of Business Finance \& Accounting, 30 (910), 1173-1210.

Ferreira, M. A., M. Massa, and P. Matos. 2010. Shareholders at The Gate? Institutional Investors and Cross-Border Mergers and Acquisitions. The Review of Financial Studies, 23 (2), 601-644.

Francis, J., R. LaFond, P. Olsson, K. Schipper. 2004. Cost of Equity and Earnings Attributes. The Accounting Review, 79 (4), 967-1010.

Grinstein, Y., and R. Michaely. 2005. Institutional Holdings and Payout Policy. The Journal of Finance, 60 (3), 1389-1426.

Grossman, S. J., and O. D. Hard. 1980. Takeover Bids, The Free-Rider Problem, and The Theory of The Corporation. Bell Journal of Economics, 11, 42-54.

Hartzell, J., and L. Starks. 2003. Institutional Investors and Executive Compensation. Journal of Finance, 58 (6), 2351-2374.

Howe, K., M., H. Jia, and G. W. Kao. 1992. One-Time Cash Flow Announcements and Free Cash-Flow Theory: Share Repurchases and Special
Dividends. The Journal of Finance, 47 (5), 1963-1975.

Jagannathan, M., C. Stephens, and M. Weisbach. 2000. Financial Flexibility and The Choice Between Dividends and Stock Repurchase. Journal of Financial Economics, 57 (3), 355-384.

Jensen, M., and W. Meckling. 1976. Theory of The Firm: Managerial Behavior, Agency Costs, and Ownership Structure. Journal of Financial Economics, 3 (4), 305-360.

Jensen, M. C. 1986. Agency Costs of Free Cash Flow, Corporate Finance, and Takeovers. The American Economic Review, 76 (2), 323-329.

Jeon, J. Q., C. Lee, and C. M. Moffett. 2011. Effects of Foreign Ownership on Payout Policy: Evidence from The Korean Market. Journal of Financial Markets, 14 (2), 344-375.

Khanna, T., and K. G. Palepu. 1999. Emerging Market Business Group, Foreign Investors, and Corporate Governance. In: Morck, R. (Ed.), Concentrated Corporate Ownership, NBER. University of Chicago Press, 265-294.

La Porta, R., F. L. De-Silanes, A. Shleifer, and R. W. Vishny. 2000a. Investor Protection and Corporate Governance. Journal Finance Economics, 58 (1), 327.

La Porta, R., F. L. De-Silanes, A. Shleifer, and R. W. Vishny. 2000b. Agency Problems and Dividend Policies Around the World. Journal of Financial Economics, 55 (5), 1-33.

Li, K., and X. Zhao. 2008. Asymmetric Information and Dividend Policy. Financial Management, 37 (4), 673694.

Maug, E. 1998. Large shareholders as monitors: Is There a Trade-Off 
Between Liquidity and Control? The Journal of Finance, 53 (1), 65-98.

Mancinelli, L., and A. Ozkan. 2006. Ownership Structure and Dividend Policy: Evidence from Italian Firms. The European Journal of Finance, 12 (3), 265-282.

Miller, M., and F. Modigliani. 1961. Dividend Policy, Growth, and The Valuation of Shares. Journal of Business, 34, 411-433.

Moin, A., Y. Guney, and I. El Kalak. 2019. The Effect of Ownership Structure, Sub-Optimal Cash Holdings and Investment Efficiency on Dividend Policy: Evidence from Indonesia. Review of Quantitative Finance and Accounting, 5, 857-900.

Mulyani, E., H. Sigh, and S. Mishra. 2016. Dividends, Leverage and Family Ownership in the Emerging Indonesian Market. Journal of International Financial Markets, Institutions and Money, 43, 16-29.

Pagalung, G. and B. Sudibyo. The Determinant Factors of Earnings Quality and Economic Consequences. Ekuitas: Jurnal Ekonomi dan Keuangan 16 (1), 105-122.

Rhee, S. G., and J. Wang. 2009. Foreign Institutional Ownership and Stock Market Liquidity: Evidence from Indonesia. Journal of Banking and Finance, 33 (7), 1312-1324.

Setiawan, D., B. Bandi, L. K. Phua, and I. Trinugroho. 2016. Ownership Structure and Dividend Policy in Indonesia. Journal of Asia Business Studies, 14 (56), 135-143.

Warrad, L., S. Abed, O. Khriasat, and I. AlSheikh. 2012. The Effect of Ownerhsip Structure on Dividend Payout Policy: Evidence from Jordanian Context. International Journal of Economics and Finance 4 (2), 187-195.
Yaram, S. R. 2015. Corporate Governance Ratings and the Dividend Payout Decisions of Australian Corporate Firms. International Journal of Managerial Finance, 11 (2), 162-178. 